\title{
Habitat selectivity of megalopae and juvenile mud crabs (Scylla serrata): implications for recruitment mechanism
}

\author{
James A. C. Webley*, Rod M. Connolly, Ruth A. Young \\ Australian Rivers Institute - Coasts and Estuaries, and Griffith School of Environment
}

Griffith University, QLD 4222, Australia

\begin{abstract}
Megalopae of several crab species exhibit active habitat selection when settling. These megalopae usually select structurally complex habitats which can provide refuge and food. The portunid mud crab, Scylla serrata, is commonly found within the muddy estuaries of the Indo-West Pacific after attaining a carapace width $>40 \mathrm{~mm}$. Despite substantial efforts, the recruitment mechanism of juvenile mud crabs to estuaries is not understood because their megalopae and early stage crablets (carapace width $<30 \mathrm{~mm}$ ) are rarely found. We used laboratory experiments to determine whether megalopae and early stage crablets are selective among three estuarine habitats which commonly occur in Queensland, Australia. These animals were placed in arenas where they had a choice of habitats: seagrass, mud or sand, and arenas where they had no choice. Contrary to the associations exhibited by other portunid crab megalopae, $S$. serrata megalopae were not selective among these estuarine habitats, suggesting that they tend not to encounter these habitats, or, gain no advantage by selecting one over the others. The crablets, however, strongly selected seagrass, suggesting that residing within seagrass is beneficial to the crablets and likely increases survival. This supports the model that for $S$. serrata, crablets and not megalopae tend to colonise estuaries, since a selective behaviour has evolved within crablets but not megalopae.
\end{abstract}

\section{Introduction}

Organisms are rarely randomly distributed throughout the environment (Condit et al. 2000; Bertness et al. 2001). For animals, this non-random distribution is generated by mechanisms that may or may not involve habitat choice. Mortality is one mechanism; animals which recruit randomly and subsequently die in inhospitable places but survive elsewhere will be non-randomly distributed and associated with the hospitable habitats (Crowe and Underwood 1998). This mechanism does not require the exercise of choice or selection yet generates habitat associations. Alternatively, animals may make choices about where they live. For pelagic larvae, choices among settlement habitats may initially establish a non-random distribution (Orth and van Montfrans 1987; Moksnes 2002). Postsettlement movements of individuals towards particular chosen habitat types can redistribute the population (Moksnes 2002; Lecchini et al. 2007). These latter mechanisms involve the selection of particular habitats to create non-random distributions of animals.

Organisms are constantly faced with choices, for example choices about feeding, habitat, and breeding. It is a tenet of evolutionary theory that, collectively, these choices or selections serve to enhance the fitness of future generations (Gould and Lewontin 1979; Krebs and Davies 1997). The postlarvae of several decapod species actively choose to settle to habitats that provide refuge or abundant food, or move into these beneficial habitats shortly after settling (Dionne et al. 2003; Moksnes et al. 2003; van Montfrans et 
al. 2003). Understanding which habitats are chosen by settling animals enables us to rank the habitats according to the likelihood that they enhance the survival of that species.

Places that increase the probability of juveniles surviving and subsequently contributing to future generations can be considered nursery habitats (Beck et al. 2001). Nursery habitats might not, however, be the dominant contributor to future adult populations. Their area may be small compared to other habitats and therefore, despite being relatively more productive, they could contribute a smaller proportion of the future adults compared to larger habitats (Dahlgren et al. 2006). However, highly productive places such as nursery habitats may provide the population a degree of reproductive resilience, which is important during periods of disturbance (Apostolaki et al. 2002). Nursery habitats, therefore, may contribute subtly to the persistence of populations over an evolutionary timescale by enhancing the success of juvenile recruitment in times of more variable disturbance.

Seagrass beds are often cited as nursery habitats for juvenile marine animals because they provide refuge from predators and a greater abundance of food (Jackson et al. 2001). For example, the juveniles of two portunid species, the North American blue crab (Callinectes sapidus) and Indo-West Pacific blue swimmer crab (Portunus pelagicus) are associated with seagrass (Orth and van Montfrans 1987; Kenyon et al. 1999). Refuge may be provided by the complex structure of seagrass beds restricting the movement of larger animals potentially preying on the small juveniles. Paradoxically however, the greater abundance of small animals seeking refuge within these habitats may attract more of their predators, preying on those seeking shelter (Connolly 1994; Franco et al. 2006).

The postlarvae of many decapod species are strongly selective among settlement habitats, tending to select habitats with complex structures. For example, the number of Carcinus maenas postlarvae settling to structurally complex habitats such as mussel, algae, and eelgrass patches was more than ten times greater than that settling to sand (Moksnes 2002). Where juvenile marine animals strongly select for particular habitats, the behaviour has likely evolved over time because of the benefits gained, such as refuge from predation and enhanced growth (Perkins-Visser et al. 1996; Moksnes et al. 1998).

The mud crab (Scylla serrata) is an economically and recreationally important portunid crab distributed throughout the coasts of the Indo-West Pacific. Adult mud crabs are generally found in muddy, mangrove-lined estuaries, and the ovigerous females move offshore to spawn (Hill 1994). Crabs which have a dispersive coastal larval stage and occur within estuaries as adults, usually colonise coastal habitats as megalopae or postlarvae. For example, the velvet swimmer crab megalopae (Necora puber) and blue crab megalopae colonise estuaries and tend to settle to complex estuarine habitats (Tankersley et al. 2002; Lee et al. 2006). Despite considerable searching effort however, mud crab megalopae (total length ca. $5 \mathrm{~mm}$ ) are rarely found within estuaries (Arriola 1940; Heasman 1980; Forbes and Hay 1988; Knuckey 1999; Moser and Macintosh 2001; Walton et al. 2006). Explanations for rarely finding mud crab megalopae include episodic recruitment, cryptic behaviour, or simply that they tend not to colonise estuaries as megalopae.

In Australia, mud crab crablets (carapace width (CW) $<30 \mathrm{~mm}$ ) are also rarely seen despite the considerable amount of estuarine field research. They have been found however, in seagrass at a river mouth (D. Mann, Queensland Department of Primary Industries and Fisheries, pers. comm.), under debris and stones in bayside patches of 
sheltered mangroves (Heasman 1980), on sand bars near a river mouth (Mounsey 1990), and in baited traps in shallow saltmarsh creeks (L. Anderson, Central Queensland University, pers. comm.). These observations are sporadic and prevent us from determining if these crablet-habitat associations are representative or exceptional. However, if mud crab crablets do colonise estuaries then we speculate that they will be selective among estuarine habitats as has been the case for other crabs, because it is unlikely that all habitats offer equivalent benefits (Moksnes 2002; van Montfrans et al. 2003; Moksnes and Heck 2006).

Webley and Connolly (2007) proposed a coastal settlement model that pelagic mud crab megalopae settle on the coastal shelf in the nearshore region, possibly behind the surf zone, as suggested for the prawn Penaeus plebejus (Rothlisberg et al. 1995). There, the megalopae metamorphose into benthic crablets which utilise along-shore currents and flooding tides to colonise estuaries, keeping close to the substratum. At the mouths of estuaries in southeast Queensland, the subtidal substratum tends to be dominated by a mosaic of sandy or muddy habitats with patches of seagrass. As crablets colonise estuaries from the nearshore region they likely encounter these habitats before moving upstream to stands of mangroves.

This model is controversial because it suggests that for mud crabs, crablets and not megalopae tend to colonise estuaries, whereas for several other portunids, the megalopa is the colonising stage (Moksnes 2002; Tankersley et al. 2002). This model implies that mud crab megalopae tend not to encounter estuarine habitats and therefore are unlikely to be selective among the habitats found there. Mud crab crablets, however, are predicted to colonise estuaries and encounter and utilise the benefits of the structurally complex habitats such as seagrass. Specifically we predicted that: (1) S. serrata crablets would select seagrass habitats over mud or sand, and (2) megalopae would show no selectivity among the estuarine habitats: seagrass, mud, and sand. This second hypothesis is a demanding test for the coastal settlement model to pass, because many other portunid megalopae selectively settle to structurally complex habitats, often with more than twice the number settling to complex habitats.

Active selection, or favouring a particular habitat, intrinsically involves an active choice by the organism. Simply being associated with or found within a particular habitat does not demonstrate an active choice for the habitat (Singer 2000; Underwood and Clarke 2006). For habitats, confounding factors such as 'accessibility' (the ability to occupy or locate a habitat) could also explain why animals occur within a particular habitat (Olabarria et al. 2002; Underwood et al. 2004). To determine if a habitat is actively selected or favoured, it is necessary to compare the behaviour of the animals when presented with a choice of habitats, to their behaviour in the absence of a choice (Underwood et al. 2004). Here, we use a commonly accepted and testable definition that active selection is demonstrated when animals select an option to a greater extent when offered a choice than could be predicted from observations of the behaviour in the absence of a choice (Barbeau and Scheibling 1994; Olabarria et al. 2002). We tested the hypotheses with laboratory experiments because these animals are small and cryptic, making it difficult to complete these experiments in the field. 


\section{Materials and methods}

\section{Rearing}

Scylla serrata megalopae and crablets were provided by Bribie Island Aquaculture Research Centre, Queensland Department of Primary Industries and Fisheries and all experiments were completed at their facilities. All were reared from a single batch of eggs extruded by a wild female crab collected from Pumicestone Passage, Queensland (153 $11^{\prime} 55^{\prime} \mathrm{E}, 27^{\circ} 03^{\prime} 04$ 'S). The larval rearing protocol followed the ambient day:night cycle (12:12) with temperatures between $27-29^{\circ} \mathrm{C}$ and salinities between 35 - 36. Mud cab megalopae can metamorphose to crablets after approximately 6 - 7 days (Baylon and Failaman 1999; Holme et al. 2007). The megalopae used here were 2 - 3 days old and therefore likely to be competent to settle before the experiment finished.

The selection experiment was done twice, once using megalopae and once using crablets $(\mathrm{CW}<8 \mathrm{~mm})$. Circular plastic tanks $(\mathrm{H}=450 \mathrm{~mm}$, dia. $=1100 \mathrm{~mm}$, area $=0.95$ $\mathrm{m}^{2}$ ) filled with sand filtered seawater (salinity 35.4, ca. $320 \mathrm{~L}$ ) were used as experimental arenas containing a choice of habitats, following van Montfrans (2003). A standpipe (6 cm dia.) which had mesh covered holes $(800 \mu \mathrm{m})$ at the bottom and top was fixed centrally within the arena and an air stone placed inside. These holes permitted a slow recirculation of water in the vertical plane when air was released from the air stone. Both the megalopae and the crablets were easily able to move against this current. The arenas were divided into three equal segments by inserting dividers between the standpipe and the arena wall. A habitat, sand (S), mud (M) and seagrass (G), was added to each segment within the arenas (Fig. 1). All habitats were collected locally. The seagrass was predominantly Zostera capricorni rooted in a muddy/sandy substrate, with a three dimensional structure (determined from seven haphazardly placed $900 \mathrm{~cm}^{2}$ quadrats) as follows: mean (SE) shoots per quadrat 129 (11.8), with 3 (0.1) blades per shoot, a blade length of 103 (6.1) $\mathrm{mm}$ and width of $2.4(0.1) \mathrm{mm}$.

The 18 arenas were haphazardly arranged in a laboratory with a translucent roof providing a natural day:night cycle. The experiment was completed indoors to reduce temperature fluctuations (mean $21.6^{\circ} \mathrm{C}$, SE 0.03 ) and crab mortality. The arenas were filled with seawater, dividers inserted and habitats added. Infauna was not removed from habitats because it may contribute to cues causing habitat selection. Sand, sods of seagrass, and mud and were carefully placed within the arenas. After adding the habitats to arenas in segment combinations shown in Fig. 1, the arenas were left to settle for 3 days before the megalopae or crablets were added. 


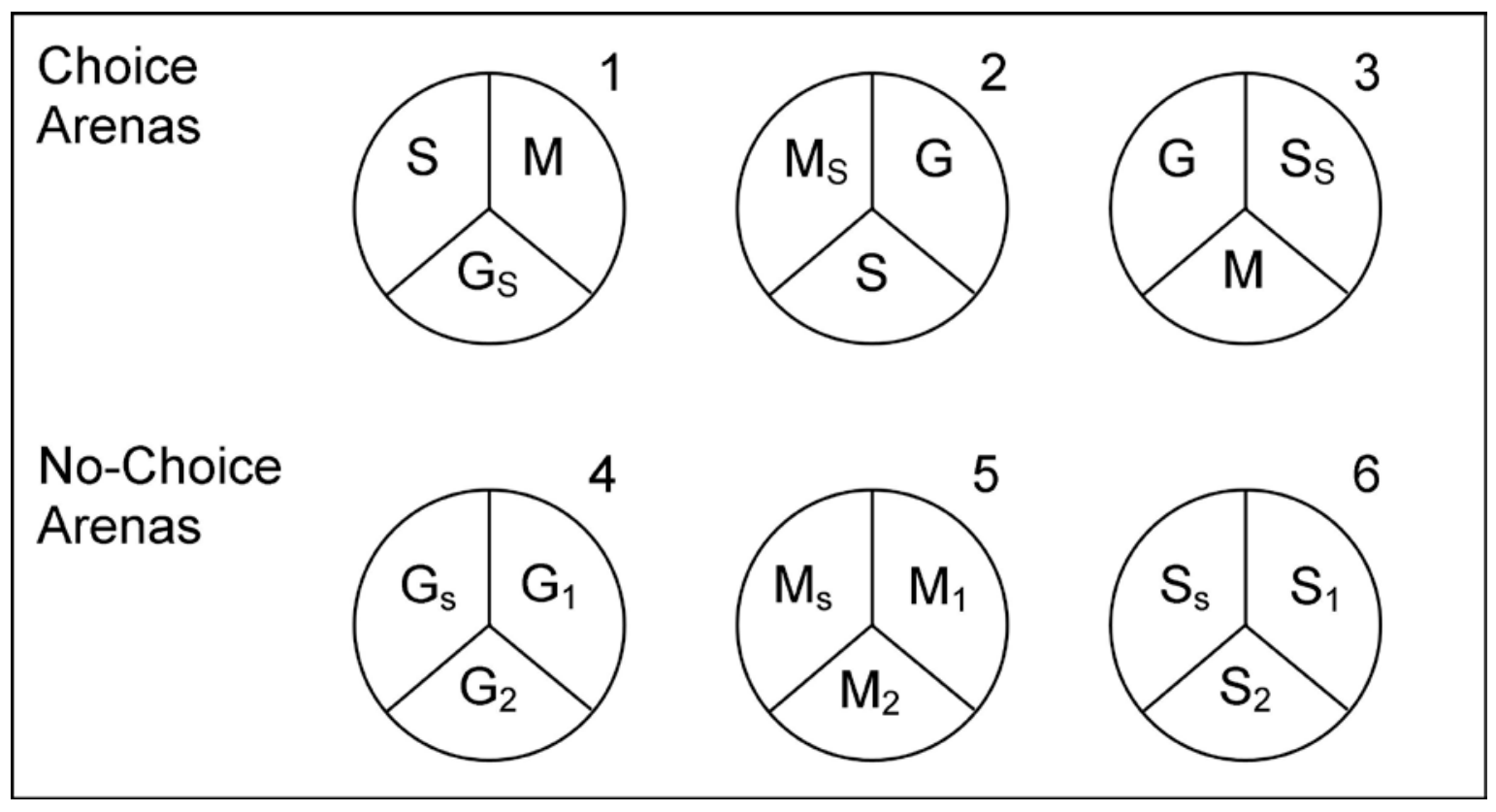

Fig. 1 A diagrammatic representation of one replicate of the experiment showing arenas with a choice (Choice: 1 3) and without a choice (No-Choice: 4 - 6). Each arena was divided into 3 segments; each segment contained only sand (S), mud (M) or seagrass (G). The Habitat Starting Segments are identified with a subscript s (e.g. $\left.G_{s}\right)$. There were three replicates of each arena, 18 in total.

The megalopae and crabs were randomly selected from the rearing facility, allocated to 18 batches of 100 (megalopae) or 10 (crablets) and then randomly allocated to an arena start segment only (denoted by a subscript 's' in Fig. 1). At this point the dividers were removed. The animals were free to roam for 3 days, then the dividers were reinserted and the arenas drained by puncturing the bottom of the standpipe. The habitats from each segment were washed and sieved (salt water, $2 \mathrm{~mm}$ mesh) and the retained material placed in $70 \%$ ethanol and carefully searched in the laboratory and recovered animals counted. The proportion of megalopae and crablets recovered within each segment was calculated by dividing by the total megalopae or crablets recovered from each arena. 
Experimental design and analysis

Placing animals within a single segment allowed us examine the extent to which the animals chose to leave or remain in that segment in the presence or absence of choice. Animals were considered to select seagrass if the proportion found in seagrass where they had a choice of habitats, was greater than would have been predicted from their distribution in the absence of choice (Olabarria et al. 2002; Underwood et al. 2004).

The experiment had 2 factors: Choice (2 levels; Choice and No-Choice) and Habitat Start Segment (3 levels; Start in Seagrass, Mud or Sand) and was replicated 3 times (Fig. 1). Megalopae and crablet data were analysed separately. Selectivity for seagrass was demonstrated if a greater proportion of animals occurred in the seagrass start segments within Choice arenas $\left(\mathrm{G}_{s}\right.$, Arenas $\left.1 ; n=3\right)$ than in the seagrass start segments within No-Choice arenas $\left(\mathrm{G}_{\mathrm{s}}\right.$, Arenas $\left.4, n=3\right)$. Likewise, the proportion that occurred in the start segments for mud $\left(\mathrm{M}_{\mathrm{s}}\right.$, Arenas 2, $\left.n=3\right)$ and sand $\left(\mathrm{S}_{\mathrm{s}}\right.$, Arenas 3, $\left.n=3\right)$ within Choice arenas would be less than in start segments within the respective No-Choice arenas $\left(\mathrm{M}_{\mathrm{s}}\right.$, Arenas 5 and $\mathrm{S}_{\mathrm{s}}$ Arenas 6; $\left.n=3\right)$. Data were proportions and arc-sine transformed. Cochran's test was used to test for heterogeneity of variance. The selectivity hypothesis was tested using ANOVA, where a significant Choice $\times$ Habitat Start Segment interaction $\left(\mathrm{C} \times \mathrm{H}_{\mathrm{s}}\right)$ would support selectivity. Student-Newman-Keuls (SNK) tests followed significant interaction effects to determine which habitats the megalopae or crablets selected. The main factors do not test the hypothesis of a difference in behaviour in the presence or absence of choice, therefore SNK tests were not done for these terms.

For reasons that are not clear, fewer megalopae were recovered from the seagrass No-Choice arenas than from the other habitat types (Table 1). This may be a legitimate result caused by greater mortality within seagrass, or an artefact if we were inefficient at recovering megalopae from the seagrass habitat. If this were solely due to our ability to recover megalopae from seagrass then it is likely that a similar loss of megalopae occurred within the seagrass segments within Choice arenas. To compensate for this possibility, the data were adjusted as follows. The number of megalopae found within seagrass segments of the Choice arenas were multiplied by the deficiency between the mean recovery rates of megalopae from the seagrass No-Choice arenas and the mud and sand No-Choice arenas (2.43 times). The adjusted data were reanalysed using the same ANOVA procedures outlined above.

To determine if there was a significant difference in the recovery of animals from different habitat types the animals recovered from each replicate of the No-Choice arenas (Arenas 4, 5 and 6; Fig. 1) were compared using ANOVA (Single factor: Habitat, 3 levels, $n=3)$.

To determine if the animals had sufficient time and ability to disperse through the entire arena, their distribution through the different segments of the No-Choice treatments was analysed. For each segment, the proportion of the total number of animals recovered from the respective No-Choice arena was calculated. ANOVA on arc-sine transformed data tested the factors Habitat (3 levels: Seagrass, Mud and Sand, Fixed), Segment (3 levels: Start segment and segment $1 \& 2$, Fixed) and their interaction. 


\section{Animals recovered}

Megalopae

(100/arena initially added)
Crablets

(10/arena initially added)

\begin{tabular}{lcccc} 
No-Choice Arena & Individuals & Proportion & Individuals & Proportion \\
& & & & \\
\hline Seagrass & $10.0(6.0)$ & $0.10(0.06)$ & $10.0(0.0)$ & $1.00(0.0)$ \\
Mud & $24.3(5.2)$ & $0.24(0.05)$ & $7.3(0.9)$ & $0.73(0.09)$ \\
Sand & $24.3(4.8)$ & $0.24(0.05)$ & $9.7(0.3)$ & $0.97(0.03)$ \\
& & & & \\
\hline
\end{tabular}

Power analysis

The second hypothesis is a statistical null hypothesis (Underwood 1991) and therefore requires a power analysis to interpret the results. Two power analyses were done, one with an effect size of 1 - 2 fold more megalopae in seagrass segments and the other with a 2 - 3 fold effect. These effect sizes are at the conservative end of the range observed for other crabs (2 - 10 fold effect e.g. Moksnes 2002). The number of megalopae in seagrass was generated by multiplying the average abundance of megalopae within the respective mud and sand segments of the choice arenas by a random number between either 1 - 2 or 2 - 3, providing two data sets with a restricted variable effect size. Abundance data were converted to proportions, arc-sine transformed, and the power to detect a $\mathrm{C} \times \mathrm{H}_{\mathrm{s}}$ interaction calculated using PiFace Ver 1.65 software (Lenth 2007).

\section{Results}

In total, 346 megalopae (19\%) were recovered from arenas. Within the No-Choice arenas, the mean number of megalopae recovered from seagrass arenas was less than half that recovered from either the mud or the sand arenas, however the difference was not significant (Cochran's test $=n s$ : ANOVA $d f 2,6 ; P>0.17$ :Table 1 ). A total of 144 crablets $(80 \%)$ were recovered from the arenas. Within the No-Choice arenas, all crablets were recovered from seagrass arenas and almost all were recovered from the mud and sand arenas. These were not tested using ANOVA because there was no variance within the 
seagrass No-Choice arenas and large proportions of the crablets were recovered in all habitat types (Table 1).

\section{Megalopae}

The megalopae showed no selectivity among the habitats offered. There was no significant Choice $\times$ Habitat Start Segment interaction $\left(\mathrm{C} \times \mathrm{H}_{\mathrm{s}}\right)$ nor any significant main effect (Table 2, Fig 2). There was no significant effect of the habitat type among the NoChoice arenas, nor any significant difference in the distribution of megalopae among segments within the No-Choice arenas (Table 3).

Table 2: ANOVA (megalopae and crablets) and SNK tests (crablets only) for the hypothesis that there is a significant interaction between presence or absence of Choice (C) and Habitat Start Segment $\left(\mathbf{H}_{\mathrm{s}}\right)$. Cochran's test =ns.

\begin{tabular}{lccccc}
\hline & \multicolumn{3}{c}{ Megalopae } & \multicolumn{2}{c}{ Crablets } \\
Source of variance & $\boldsymbol{d} f$ & $\boldsymbol{F}$ & $\boldsymbol{P}$ & $\boldsymbol{F}$ & $\boldsymbol{P}$ \\
\hline Choice & 1 & 0.82 & 0.382 & 3.56 & 0.084 \\
Habitat Start Segment & 2 & 3.73 & 0.055 & 11.83 & 0.002 \\
& & & & & \\
$\mathbf{C} \times \mathbf{H}_{\mathbf{s}}$ & $\mathbf{2}$ & $\mathbf{0 . 1 8}$ & $\mathbf{0 . 8 3 4}$ & $\mathbf{1 5 . 6 7}$ & $\mathbf{0 . 0 0 1}$ \\
Residual & & & & & \\
& 12 & & & & \\
\hline
\end{tabular}

SNK comparisons for $\mathbf{C} \times \mathbf{H}_{\mathrm{s}}$ interaction for crablets

Habitat Start Segment $\quad P \quad$ Direction

\begin{tabular}{lcc}
\hline Seagrass & $<0.01$ & Choice $>$ No Choice \\
Mud & ns & Na \\
Sand & $<0.05$ & Choice $<$ No Choice \\
& & \\
\hline
\end{tabular}




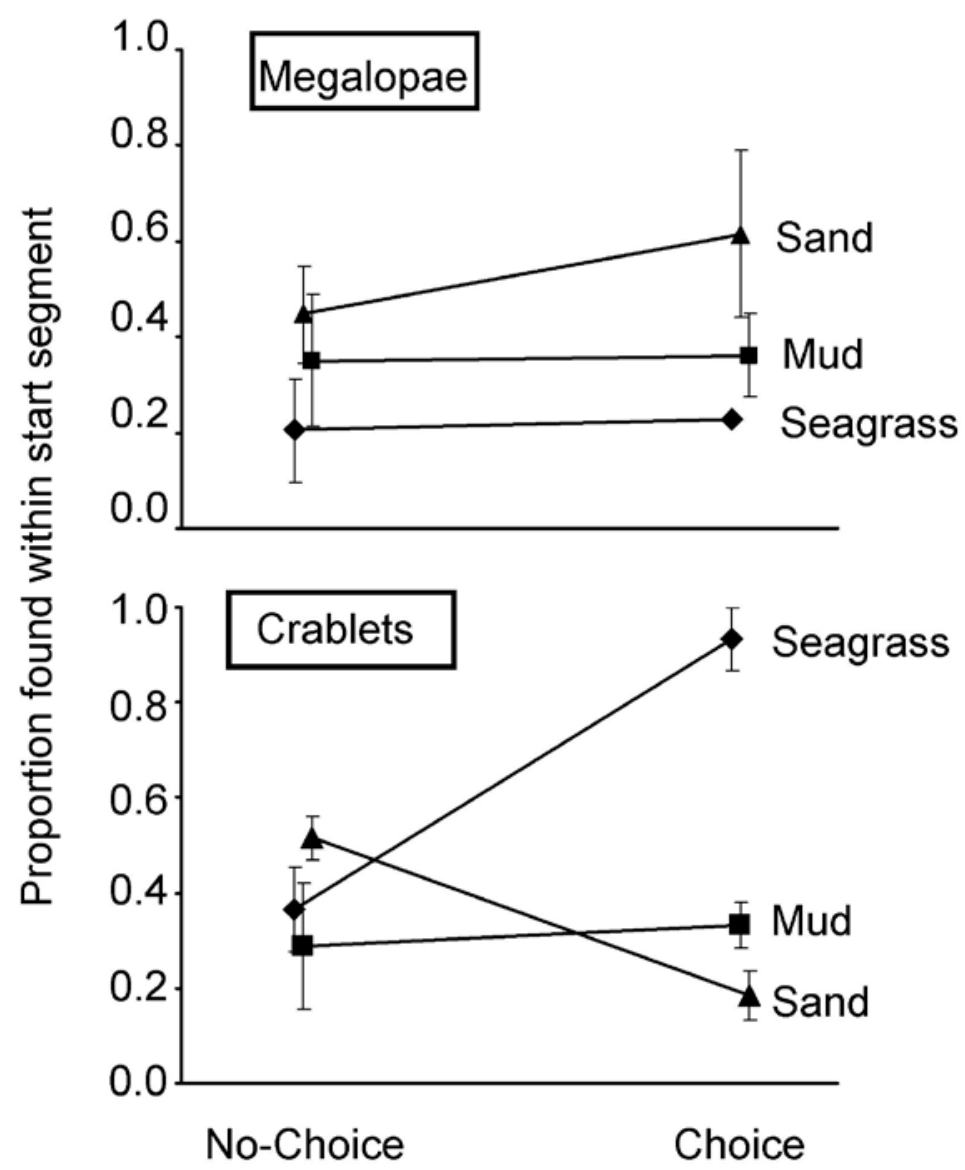

Fig. 2 The interaction between the presence or absence of Choice and the Habitat Start Segment $\left(C \times \mathbf{H}_{s}\right)$ for megalopae and crablets. Data are mean (SE) number of animals found within the start segment as a proportion of the animals recovered from each arena for the different habitat types within No-Choice and Choice arenas $(n=3)$.

The selectivity hypothesis was retested after adjusting megalopae data for the recovery deficiency of 2.43 times. These adjusted data also showed no selectivity among the habitats offered; the $\left(\mathrm{C} \times \mathrm{H}_{\mathrm{s}}\right)$ interaction was not significant (Table 4).

\section{Crablets}

There was a significant $\mathrm{C} \times \mathrm{H}_{\mathrm{s}}$ interaction (Table 2; Fig 2). Significantly more crablets were found in seagrass within Choice arenas than could be predicted from the NoChoice arenas, demonstrating selectivity for seagrass (Table 2). Significantly fewer crablets were found in sand within Choice arenas than predicted from the No-Choice arenas, demonstrating a bias against sand (Table 2). The proportion of crablets found in mud within Choice arenas was consistent with that predicted from the No-Choice arenas, demonstrating an indifference to mud (Table 2). In the Choice arenas, the proportion of crablets found in seagrass segments was always greater than for either mud or sand, regardless of the habitat in which they started (Fig. 3). Within the No-Choice arenas, there was no significant difference in the distribution of crablets either within or among habitat types, nor any interaction (Table 3; Fig. 4). 


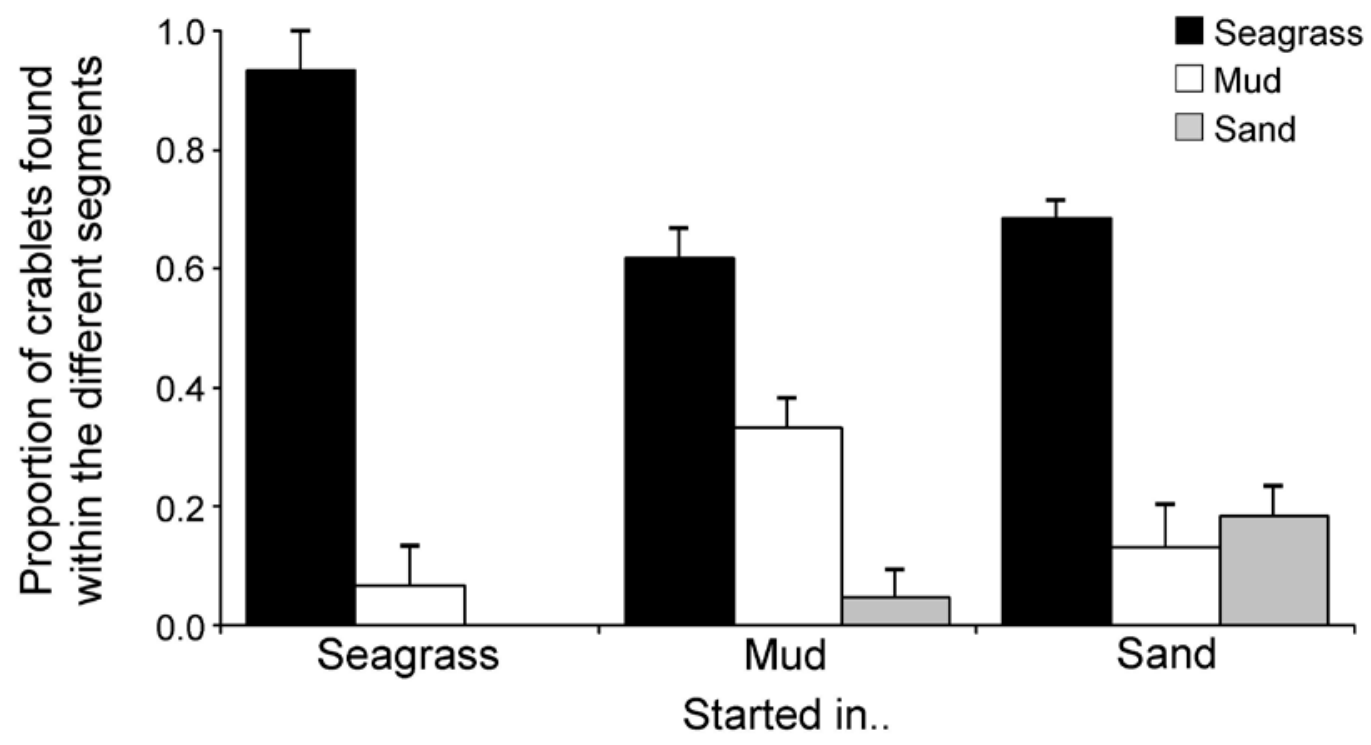

Fig. 3 Crablets found within the segments of the Choice arenas where crablets started in seagrass, mud or sand (data are mean (SE) proportions of total recovered).

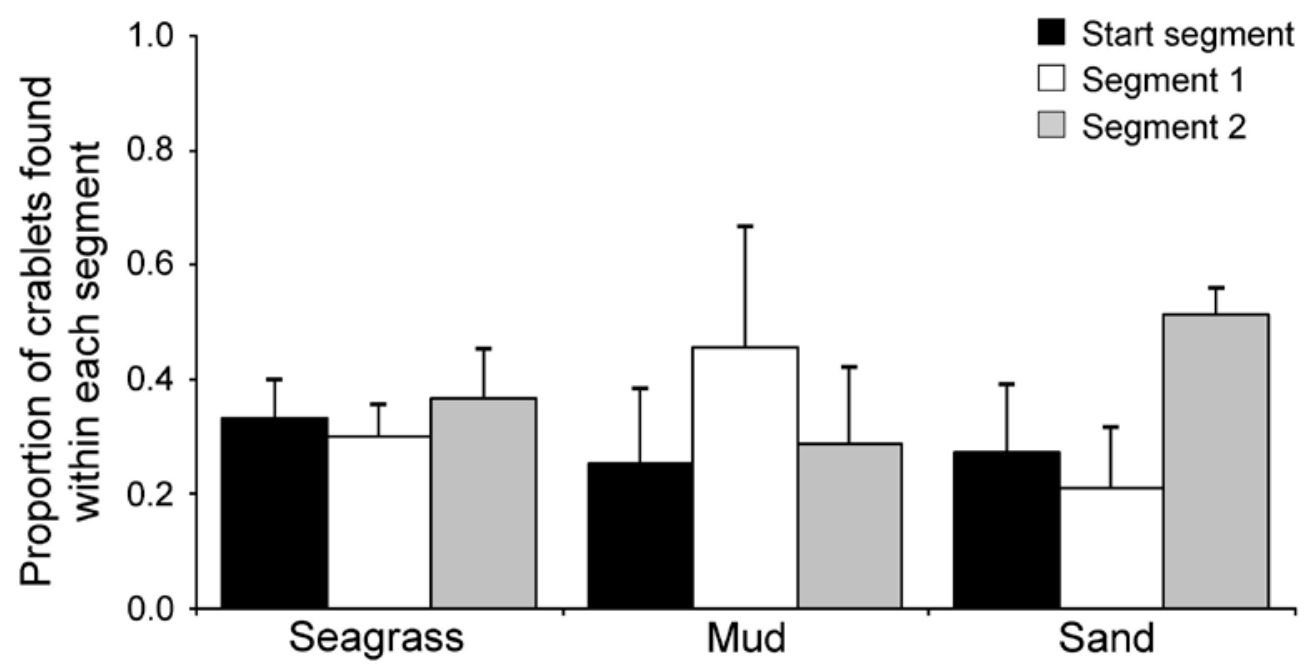

Fig. 4 Crablets found within the segments of the No-Choice arenas for seagrass, mud and sand (data are mean (SE) proportions of total recovered). 
Table 3: ANOVA for an effect of Habitat or Segment on the distribution of megalopae and crablets within NoChoice arenas. Cochran's test $=n s$.

\begin{tabular}{lccccc}
\hline & \multicolumn{2}{c}{ Megalopae } & \multicolumn{2}{c}{ Crablets } \\
Source of variance & $\boldsymbol{d} \boldsymbol{f}$ & $\boldsymbol{F}$ & $\boldsymbol{P}$ & $\boldsymbol{F}$ & $\boldsymbol{P}$ \\
\hline Habitat & 2 & 0.03 & 0.968 & 0.06 & 0.939 \\
Segment & 2 & 0.01 & 0.992 & 2.53 & 0.108 \\
Habitat $\times$ Segment & 4 & 1.01 & 0.426 & 1.30 & 0.306 \\
Residual & & & & & \\
\end{tabular}

Table 4: ANOVA for megalopae adjusted for lower recovery rates from seagrass segments to test the hypothesis that there is a significant interaction between Choice $(C)$ and Habitat Start Segment (Hs). Cochran's test $=$ ns.

\section{Megalopae}

\begin{tabular}{lccc} 
Source of variance & $\boldsymbol{d} \boldsymbol{f}$ & $\boldsymbol{F}$ & $\boldsymbol{P}$ \\
\hline Choice & 1 & 0.77 & 0.398 \\
Habitat Start Segment & 2 & 0.79 & 0.477 \\
$\mathbf{C} \times \mathbf{H}_{\mathbf{s}}$ & $\mathbf{2}$ & $\mathbf{2 . 0 6}$ & $\mathbf{0 . 1 7 0}$ \\
& & & \\
Residual & 12 & & \\
\hline
\end{tabular}

Power Analysis

The power of the experimental design to detect selectivity $\left(\mathrm{C} \times \mathrm{H}_{\mathrm{s}}\right)$ when there was a 1 - 2 or a 2 - 3 fold greater abundance of megalopae within seagrass than in mud and sand was 0.72 and 0.98 respectively (Table 5). 
Table 5: Two power analyses of the experimental design testing the hypothesis that there is a significant interaction between the presence or absence of Choice $(C)$ and Habitat start segment $\left(H_{s}\right)$ for two effect sizes, being 1-2 and 2-3 times greater abundance of megalopae within seagrass segments. Cochran's test $=n s$.

\section{Power}

Effect size

1 - 2 times

Source of variance

df

1,2

0.32

0.57

Habitat Start Segment

2, 2

0.63

0.06

$\mathrm{C} \times \mathrm{H}_{\mathrm{s}}$

2, 12

0.72

0.98

\begin{tabular}{lccc}
\hline Choice & 1,2 & 0.32 & 0.57 \\
Habitat Start Segment & 2,2 & 0.63 & 0.06 \\
$\mathbf{C} \times \mathbf{H}_{\mathbf{s}}$ & $\mathbf{2 , 1 2}$ & $\mathbf{0 . 7 2}$ & $\mathbf{0 . 9 8}$
\end{tabular}

Residual

Effect size

2 - 3 times 


\section{Discussion}

No significant $\mathrm{C} \times \mathrm{H}_{\mathrm{s}}$ interaction was detected in the megalopae experiment, supporting the model that megalopae are not selective among the habitats offered. The power analysis shows that if habitat selection by mud crab megalopae is as pronounced as for other portunid species, then the experimental design had reasonable power to detect it. It is therefore reasonable to conclude that mud crab megalopae are not strongly selective among the habitats presented. The low overall recovery of megalopae and the different recovery rates from the seagrass, sand and mud No-Choice arenas does, however, complicate the interpretation of these results.

Although not significantly different, the mean number of megalopae recovered from the seagrass No-Choice arenas was less than half that recovered from the sand or mud arenas. If this was solely due to the ability to recover megalopae from seagrass then it is likely that there was a similar inefficiency of megalopae recovered from seagrass segments within Choice arenas. Adjusting the data for this artefact increases the proportion of megalopae found in seagrass segments and reduces the proportion found elsewhere, but even these adjusted data showed no significant $\mathrm{C} \times \mathrm{H}_{\mathrm{s}}$ interaction, supporting the hypothesis of lack of selectivity among habitats.

Fewer megalopae were found in the seagrass habitat within Choice arenas. Aside from less efficient recovery from the seagrass habitat, this may also be the result of post-settlement mortality or movement. Post-settlement mortality may be due to many factors including predation and cannibalism and these processes may have different rates in different habitats. Mud crab megalopae are cannibalistic and may also have eaten those metamorphosing into first instar crablets (Rabbani and Zeng 2005). Blue crab megalopae are cannibalistic at high densities, but generally only over unvegetated habitats (Moksnes et al. 1997). Other studies suggest that that the structural complexity of seagrass provides refuge from predation and cannibalism and reduces mortality (Moksnes et al. 1997; Moksnes et al. 1998). If mortality explains why fewer megalopae were found within the seagrass segments, then it is difficult to argue that seagrass is a beneficial refuge for mud crab megalopae. Competition for space can also drive animals from favourable habitats. With fewer megalopae recovered from seagrass segments than mud or sand, competition for space should have driven megalopae into seagrass segments, not out of them.

As animals grow, the benefits of a particular habitat can change. It may become advantageous for those animals to migrate to different habitats, disguising initial settlement patterns (Moksnes and Heck 2006; Lecchini et al. 2007). In the current experiment we reduced the possibility of ontogenetic post-settlement migrations confounding the results by examining megalopae and crablets separately and running the experiment for only 3 days. The results show no pronounced selectivity among habitats and therefore, it is unlikely that megalopae strongly select seagrass over mud or sand to the extent exhibited by other species of crab.

In contrast to megalopae, the recovery rate of crablets was high (80\%) and similar across the different habitats of the No-Choice arenas. The significant $\mathrm{C} \times \mathrm{H}_{\mathrm{s}}$ interaction showed that crablets strongly selected seagrass, were indifferent towards mud, and rejected sand. Where crablets had a choice, more were found within the seagrass segments than within mud or sand, regardless of which habitat they started in. Crablets tended to either remain in or move into seagrass. 
Since habitats such as seagrass extend into the water column and create an aboveground structure, the possibility that seagrass restricts the movement of crablets should be considered in the current experiment. If crablets are thought of as simple clockwork toys, randomly moving around the arenas with their velocity reduced within seagrass segments, then they would tend to accumulate within the seagrass. Whilst theoretically possible, this scenario is unrealistic. In this experiment the crablets had sufficient time to sample the other habitats, as demonstrated by their distribution throughout the seagrass No-Choice arenas. They were also observed several times to simply swim over or around the seagrass segment whilst exploring the arenas. Therefore the simplest explanation is that they selected the seagrass and tended to choose to remain there.

As with all laboratory experiments, these results should be interpreted with caution because the animals were subject to artificial conditions and the facilities did not allow us to test settlement patterns under flow conditions (e.g., Lee et al. 2004). The megalopae and crablets used, although from wild stock, were reared in aquaculture facilities from one brood. Highly mobile predators such as large fish were absent from the arenas and not all estuarine habitats were offered. These artefacts may have caused crabs to behave differently to the wild populations.

Animals which do not colonise estuaries are unlikely to be selective among the habitats found there because their ancestors rarely encountered them, and selectivity is unlikely to have evolved. Together, our results are consistent with mud crab megalopae settling on the nearshore coastal shelf before colonising estuaries as crablets ( $\mathrm{CW}<30$ $\mathrm{mm}$ ) (Webley and Connolly 2007). The coastal shelf adjacent to estuaries in southeast Queensland is dominated by a sandy, unvegetated substrate (Stevens and Connolly 2005). The colonising crablets, however, would encounter estuarine habitats and if benefits were available, it is likely that selectivity among the habitats would have evolved as it has for other species (Moksnes and Heck 2006).

If, when colonising estuaries, crablets are less likely to be eaten than megalopae, then a fitness benefit may exist for nearshore settlement of megalopae and subsequent metamorphosis into crablets before colonising estuaries. The total length of a mud crab megalopa is $4-5 \mathrm{~mm}$, a relatively large size, and it has a propensity to rise into the estuarine water column when illuminated (Webley and Connolly 2007), making it an easy target for visual predators such as resident juvenile fish. Crablets however are cryptic and have an ability to bury in the substrate. Therefore we suggest that within estuaries the mortality rate for mud crab megalopae will be greater than for crablets.

Adult mud crabs are associated with estuarine mangroves, but despite considerable search effort in several countries the crablets and megalopae are rarely found. Few mud crab megalopae are reported to be caught within bays or estuaries using plankton tows or 'hogs hair' style larvae collectors (Arriola 1940; Moser and Macintosh 2001; Sumpton et al. 2003; Walton et al. 2006). Only two reports of crablets occurring within estuaries or mangroves were found in our review of the literature. One instance is from a prawn sampling program in a South African estuary (Forbes and Hay 1988) and the other from an extensive survey of artificial habitat (roof tiles) placed within mangroves (Hill et al. 1982). Over the 17 month duration of the latter survey, fewer than 20 crablets were found under the tiles, a very small number compared to that required to maintain the adult population. Tiles have been used in a similar manner along other mangrove-lined estuaries without success (I. Knuckey, Fishwell Consulting, pers. comm.). In Vietnam, crablets of the congeneric crab, Scylla paramamosain, have been associated with the pneumatophores of 
the mangrove-mudflat boundary, but interestingly their megalopae have not (Walton et al. 2006). Mangroves were omitted from our experiment because: 1) if crablets colonise the estuaries of southeast Queensland, the first habitats they are likely to encounter are seagrass, mud or sand, and 2) it was not practical to replicate mangrove habitat within these arenas.

Many coastal marine organisms have a pelagic life stage and for these organisms, the chaotic nature of their recruitment makes testing mechanistic models difficult. Studies need to encompass large temporal and spatial scales to discern general patterns (Gaines and Bertness 1992). Where recruitment events are witnessed sporadically, such as with mud crabs, it is difficult to use these occasional observations to test among competing recruitment models. Laboratory experiments can provide insights into the biology and behaviour of these animals, in this case a selection for seagrass over mud and sand. The results obtained here are consistent with our explanation as to how mud crabs colonise estuaries. Management of harvested species is increasingly taking an ecosystem-based approach. Our experiment suggests that because of the behaviour exhibited by the crablets, seagrass beds are a potential nursery habitat for mud crabs, and if so, management of this habitat is important to maintain the resilience of the population.

\section{Acknowledgements}

We thank the staff from the Bribie Island Aquaculture Research Centre, Queensland Department of Primary Industries and Fisheries, for their rearing of megalopae and crablets. We are also grateful to K. Pitt and N. Waltham for assistance. Experiments complied with the current laws applicable to Queensland, Australia. 


\section{References}

Apostolaki P, Milner-Gulland EJ, McAllister MK, Kirkwood GP (2002) Modelling the effects of establishing a marine reserve for mobile fish species. Can J Fish Aquat Sci 59: 405-415

Arriola FJ (1940) A preliminary study of the life history of Scylla serrata (Forskal). Philip J Sci 73: 437-455

Barbeau MA, Scheibling RE (1994) Behavioral mechanisms of prey size selection by sea stars (Asterias vulgaris Verrill) and crabs (Cancer irroratus Say) preying on juvenile sea scallops (Placopecten magellanicus (Gmelin)). J Exp Mar Biol Ecol 180: 103-136

Baylon JC, Failaman AN (1999) Larval rearing of the Mud Crab (Scylla serrata) in the Phillippines. In: Keenan CP, Blackshaw A (eds) Mud Crab aquaculture and biology. Proceedings of an international scientific forum held in Darwin, Australia, 21-24 April 1997. Australian Centre for International Agricultural Research, Canberra, pp 141-146

Beck M, Heck KL, Able KW, Childers DL, Eggleston DB, Gillanders BM, Halpern B, Hays CG, Hoshino K, Minello TJ, Orth R, Sheridan PF, Weinstein MP (2001) The identification, conservation and management of estuarine and marine nurseries for fish and invertebrates. Bioscience 51: 633-641

Bertness MD, Gaines SD, Hay ME (eds) (2001) Marine community ecology. Sinauer Associates Inc, Sunderland

Condit R, Ashton PS, Baker P, Bunyavejchewin S, Gunatilleke S, Gunatilleke N, Hubbell SP, Foster RB, Itoh A, LaFrankie JV, Lee HS, Losos E, Manokaran N, Sukumar R, Yamakura T (2000) Spatial patterns in the distribution of tropical tree species. Science 288: 1414-1418

Connolly RM (1994) The role of seagrass as preferred habitat for juvenile Sillaginodes punctata (Cuv and Val) (Sillaginidae, Pisces) - habitat selection or feeding. J Exp Mar Biol Ecol 180: 39-47

Crowe TP, Underwood AJ (1998) Testing behavioural "preferences" for suitable micro habitat. J Exp Mar Biol Ecol 225: 1-11

Dahlgren CP, Kellison GT, Adams AJ, Gillanders BM, Kendall MS, Layman CA, Ley JA, Nagelkerken I, Serafy JE (2006) Marine nurseries and effective juvenile habitats: concepts and applications. Mar Ecol Prog Ser 312: 291-295

Dionne M, Sainte-Marie B, Bourget E, Gilbert D (2003) Distribution and habitat selection of early benthic stages of snow crab Chionoecetes opilio. Mar Ecol Prog Ser 259: $117-128$

Forbes AT, Hay DG (1988) Effects of a major cyclone on the abundance and larval recruitment of the portunid crab Scylla serrata (Forskal) in the St Lucia Estuary, Natal, South Africa. S Afr J Mar Sci 7: 219-225

Franco A, Franzoi P, Malavasi S, Riccato F, Torricelli P, Mainardi D (2006) Use of shallow water habitats by fish assemblages in a Mediterranean coastal lagoon. Estuar Coast Shelf Sci 66: 67-83

Gaines S, Bertness MD (1992) Dispersal of juveniles and variable recruitment in sessile marine species. Nature 360: 579-560

Gould SJ, Lewontin RC (1979) The spandrels of San Marco and the Panglossian paradigm: a critique of the adaptationist programme. Proc R Soc B Ser 205: 581598

Heasman MP (1980) Aspects of the general biology and fishery of the mud crab Scylla serrata (Forskal) in Moreton Bay, Queensland. PhD dissertation. University of Queensland, Brisbane, Australia 
Hill BJ (1994) Offshore spawning by the portunid crab Scylla serrata (Crustacea: Decapoda). Mar Biol 120: 379-384

Hill BJ, Williams MJ, Dutton P (1982) Distribution of juvenile, subadult and adult Scylla serrata (Crustacea: Portunidae) on tidal flats in Australia. Mar Biol 69: 117-120

Holme MH, Southgate PC, Zeng C (2007) Survival, development and growth response of mud crab, Scylla serrata, megalopae fed semi-purified diets containing various fish oil : corn oil ratios. Aquaculture 269: 427-435

Jackson EL, Rowden AA, Attrill MJ, Bossey SJ, Jones MB (2001) The importance of seagrass beds as a habitat for fishery species. Ocean Mar Biol 39: 269-303

Kenyon RA, Haywood MDE, Heales DS, Loneragan NR, Pendrey RC, Vance DJ (1999) Abundance of fish and crustacean postlarvae on portable artificial seagrass units: daily sampling provides quantitative estimates of the settlement of new recruits. J Exp Mar Biol Ecol 232: 197-216

Knuckey IA (1999) Mud crab (Scylla serrata) population dynamics in the Northern Territory, Australia and their relationship to the commercial fishery. $\mathrm{PhD}$ dissertation. Charles Darwin University, Darwin, Australia

Krebs JR, Davies NB (1997) The evolution of behavioural ecology. In: Krebs JR, Davies NB (eds) Behavioural ecology: an evolutionary approach. Blackwell Science Ltd, Oxford, pp 3-12

Lecchini D, Osenberg CW, Shima JS, Mary CM, Galzin R (2007) Ontogenetic changes in habitat selection during settlement in a coral reef fish: ecological determinants and sensory mechanisms. Coral Reefs 26: 423-432

Lee J, Widdows J, Jones M, Coleman R (2004) Settlement of megalopae and early juveniles of the velvet swimming crab Necora puber (Decapoda : Portunidae) in flow conditions. Mar Ecol Prog Ser 272: 191-202

Lee JT, Coleman RA, Jones MB (2006) Population dynamics and growth of juveniles of the velvet swimming crab Necora puber (Decapoda : Portunidae). Mar Biol 148: 609-619

Lenth RV (2007) Java applets for power and sample size, Accessed: February 5, 2008, http://www.stat.uiowa.edu/ rlenth/Power/

Moksnes P-O, Lipcius RN, Pihl L, van Montfrans J (1997) Cannibal-prey dynamics in young juveniles and post-larvae of the blue crab. J Exp Mar Biol Ecol 215: 157187

Moksnes PO (2002) The relative importance of habitat-specific settlement, predation and juvenile dispersal for distribution and abundance of young juvenile shore crabs Carcinus maenas L. J Exp Mar Biol Ecol 271: 41-73

Moksnes PO, Heck KL (2006) Relative importance of habitat selection and predation for the distribution of blue crab megalopae and young juveniles. Mar Ecol Prog Ser 308: 165-181

Moksnes PO, Hedvall O, Reinwald T (2003) Settlement behavior in shore crabs Carcinus maenas: why do postlarvae emigrate from nursery habitats? Mar Ecol Prog Ser 250: 215-230

Moksnes PO, Pihl L, van Montfrans J (1998) Predation on postlarvae and juveniles of the shore crab Carcinus maenas: importance of shelter, size and cannibalism. Mar Ecol Prog Ser 166: 211-225

Moser SM, Macintosh DJ (2001) Diurnal and lunar patterns of larval recruitment of Brachyura into a mangrove estuary system in Ranong Province, Thailand. Mar Biol 138: 827-841

Mounsey R (1990) Northern Territory mud crab fishery investigation. Northern Territory Department of Primary Industries and Fisheries, Report number 19, Darwin 
Olabarria C, Underwood AJ, Chapman MG (2002) Appropriate experimental design to evaluate preferences for microhabitat: an example of preferences by species of micrograstropods. Oecologia 132: 159-166

Orth RJ, van Montfrans J (1987) Utilization of a seagrass meadow and tidal marsh creek by blue crabs Callinectes sapidus. I. Seasonal and annual variations in abundance with emphasis on post settlement juveniles. Mar Ecol Prog Ser 41: 283-294

Perkins-Visser E, Wolcott TG, Wolcott DL (1996) Nursery role of seagrass beds: enhanced growth of juvenile blue crabs (Callinectes sapidus Rathbun). J Exp Mar Biol Ecol 198: 155-173

Rabbani AG, Zeng CS (2005) Effects of tank colour on larval survival and development of mud crab Scylla serrata (Forskal). Aquac Res 36: 1112-1119

Rothlisberg PC, Church JA, Fandry CB (1995) A mechanism for near-shore concentration and estuarine recruitment of postlarval Penaeus plebejus Hess (Decapoda, Penaeidae). Estuar Coast Shelf Sci 40: 115-138

Singer MC (2000) Reducing ambiguity in describing plant-insect interactions: "preference", "acceptability" and "electivity". Ecol Lett 3: 159-162

Stevens T, Connolly RM (2005) Local-scale mapping of benthic habitats to assess representation in a marine protected area. Mar Freshw Res 56: 111-123

Sumpton W, Gaddes S, McLennan M, Campbell M, Tonks M, Good N, Hagedoorn W, Skilleter GA (2003) Fisheries biology and assessment of the blue swimmer crab (Portunus pelagicus) in Queensland. Fisheries Research and Development Corporation, Report number 98/117, Canberra, Australia

Tankersley RA, Welch JM, Forward RB (2002) Settlement times of blue crab (Callinectes sapidus) megalopae during flood-tide transport. Mar Biol 141: 863-875

Underwood AJ (1991) The logic of ecological experiments: a case history from studies of the distribution of macro-algae on rocky intertidal shores. J Mar Biol Assoc U K 71: 841-866

Underwood AJ, Chapman MG, Crowe TP (2004) Identifying and understanding ecological preferences for habitat or prey. J Exp Mar Biol Ecol 300: 161-187

Underwood AJ, Clarke KR (2006) Response on a proposed method for analysing experiments on food choice. J Exp Mar Biol Ecol 335: 151-153

van Montfrans J, Ryer CH, Orth R (2003) Substrate selection by blue crab Callinectes sapidus megalopae and first juvenile instars. Mar Ecol Prog Ser 260: 209-217

Walton ME, Le Vay L, Truong LM, Ut VN (2006) Significance of mangrove-mudflat boundaries as nursery grounds for the mud crab, Scylla paramamosain. Mar Biol 149: $1199-1207$

Webley JAC, Connolly RM (2007) Vertical movement of mud crab megalopae (Scylla serrata) in response to light: doing it differently down under. J Exp Mar Biol Ecol 341: 196-203 